\section{Despite Similar Perceptions and Attitudes, Postbaccalaureate Students Outperform in Introductory Biology and Chemistry Courses}

\author{
Erin E. Shortlidge, ${ }^{\dagger *}$ Liz Rain-Griffith, ${ }^{\dagger}$ Chloe Shelby, ${ }^{\ddagger}$ Gwendolyn P. Shusterman, ${ }^{\ddagger \S}$ \\ and Jack Barbera* \\ ${ }^{\dagger}$ Department of Biology, "Department of Chemistry, and \$STEM Education and Equity Institute, \\ Portland State University, Portland, OR 97201
}

\begin{abstract}
Embedding active learning is a common mechanism for meeting science, technology, engineering, and mathematics (STEM) education reform goals. Researchers have identified student benefits from such strategies, yet these benefits may not be universal for all students. We sought to identify how students at a nontraditional university perceive introductory biology and chemistry courses, and whether perceptions relate to course type, performance, or student status. We surveyed students $(n=601)$ using open-ended prompts regarding their perceptions of factors that impact their learning and interest, and about specific learning strategies. Generally, students did not differ in what influenced their learning or interest in course content, and students mostly perceived active learning positively. Attitudes toward active learning did not correlate to final course scores. Despite similar perceptions and attitudes, performance differed significantly among student groups-postbaccalaureates outperformed all others, and traditional-age students outperformed non-traditional-age students. We found that, even with active learning, underrepresented minority students underperformed compared to their peers, yet differentially benefited from nonsummative course factors. Although students generally perceive classroom environments similarly, undetected factors are influencing performance among student groups. Gaining a better understanding of how classroom efforts impact all of our students will be key to moving beyond supposing that active learning simply "works."
\end{abstract}

\section{INTRODUCTION}

Owing to consistently high attrition rates, efforts are being made to transform introductory courses in science, technology, engineering, and mathematics (STEM) fields (National Research Council, 2003; President's Council of Advisors on Science and Technology [PCAST], 2012). One such effort to combat the attrition rate and support undergraduate student interest in STEM is through implementing teaching strategies such as active-learning activities that are more student centered than instructor centered (Meyers and Jones, 1993; Michael, 2006; Haak et al., 2011; Freeman et al., 2014). Active learning has been defined as "instructional activities involving students in doing things and thinking about what they are doing" (Bonwell and Eison, 1991, p. 3). Examples of active learning can range from students working collaboratively in groups (Johnson et al., 1998; Tanner et al., 2003), to embedding engaging activities during lecture (Prince, 2004), to "flipped" classrooms (Herreid and Schiller, 2013). Active learning has shown a number of benefits, including increased student performance in STEM courses (Prince, 2004; Freeman et al., 2014), improved problem-solving skills and scientific reasoning (Haak et al., 2011; Jensen and Lawson, 2011), and a more welcoming introductory science classroom (Watkins and Mazur, 2013). While there is a general consensus that active learning "works" and instructors ought to be
Rebecca Price, Monitoring Editor Submitted Jan 2, 2018; Revised Oct 24, 2018; Accepted Oct 30, 2018

CBE Life Sci Educ March 1, 2019 18:ar3 DOI:10.1187/cbe.17-12-0289

*Address correspondence to: Erin E. Shortlidge (eshortlidge(apdx.edu).

() 2019 E. E. Shortlidge et al. CBE-Life Sciences Education @ 2019 The American Society for Cell Biology. This article is distributed by The American Society for Cell Biology under license from the author(s). It is available to the public under an Attribution-Noncommercial-Share Alike 3.0 Unported Creative Commons License (http://creativecommons.org/licenses/ by-nc-sa/3.0)

"ASCB®" and "The American Society for Cell Biology $\circledR^{\prime \prime}$ are registered trademarks of The American Society for Cell Biology. 
using student-centered pedagogy in their college classrooms, there is some debate about what "works" actually means (Prince, 2004; Tanner, 2011). Thus, before we assume that our classroom interventions broadly "work," it is important to study when and why efforts meet anticipated outcomes, and whether the outcomes are equitably demonstrated among different groups of students (Dolan, 2015).

A basic tenet of good teaching is that the curriculum is accessible by diverse students; this attention to diversity and equity in the classroom has been a key driver for promoting active learning (Handelsman et al., 2004; Tanner and Allen, 2004; Tanner, 2011). Researchers have begun to recognize that there may be differential outcomes from active-learning pedagogies for different groups of students in the same classroom. For example, studies have demonstrated that structuring a course to include more active learning can help close the achievement gap for some underrepresented minority (URM) groups (e.g., African-American students), but the efforts do not always have the same magnitude of effect for other URMs (e.g., Latino/a students; Eddy and Hogan, 2014). Other research has demonstrated that outcomes from active learning can differ depending on a student's gender or socioeconomic status (Haak et al., 2011; Eddy and Hogan, 2014; Eddy et al., 2014). Active-learning classrooms can thus have differential impacts, and it would be irresponsible to assume that the outcomes from an intervention at one institution would be the same for a different population of students at another institution.

A first step toward understanding the impacts of instructional practices is to understand how students perceive classroom environments and the strategies employed in those classrooms (Ames, 1992). In one study, students' negative perceptions of course workload, assessment structure, and "bad" teaching contributed to surface methods of studying (e.g., rote memorization), whereas positive perceptions of "good" teaching and appropriate assessments contributed to students using deeper methods to understand course material (Lizzio et al., 2002). Others have found that "buy-in" to course activities can lead to performance gains (Cavanagh et al., 2016). Student perceptions about active learning can vary depending upon their years in their programs (Welsh, 2012) and the specific strategies, such as formative assessments used by instructors (Brazeal et al., 2016). Other studies have reported students valuing both active-learning and traditional lecture-style courses almost equally (Yuretich, 2003; Machemer and Crawford, 2007). However, most of these studies do not report on demographic-specific differences in student perceptions. Continued efforts need to be made to understand how classroom transformations are being received by students and whether they are resulting in equitable outcomes among diverse student groups.

Although researchers are starting to look at how active learning may have dissimilar impacts among ethnic and racial groups, by gender, and/or by socioeconomic status, to date, much of this research has focused on "traditional" college students. Traditional college students have been defined as those who are 18-22 years old, have full-time status in school, live in the dormitories, do not work or have extra responsibilities, and/or tend to have started at the university straight out of high school (Choy, 2002). However, many colleges and universities around the nation do not serve only traditional student populations; thus, understanding active learning from the perspective of all student types, traditional and nontraditional, should be pursued. The National Center for Education Statistics (NCES) considers students "nontraditional" if they fall into at least one of these categories: delayed college enrollment (i.e., older), part-time enrollment status, full-time employment, financially independent (with regard to financial aid status), with dependents, and/or no high school diploma.

The enrollment of nontraditional and URM students in degree-granting institutions increased between 2000 and 2015 and is projected to continue to increase over the next 10 years (NCES, 2017). Many of these nontraditional students attend open-access institutions, such as public universities and community colleges (Doyle, 2010); therefore, classrooms in these institutions have students with wide-ranging life experiences and characteristics sitting and working side by side. Researchers have found evidence that there are differential predictors of persistence between these groups of students. For example, one study found that students' lack of an institutional commitment (e.g., only enrolling for a few credit hours, intent to leave) and low grade point average (GPA) were top predictors of attrition for nontraditional students (Metzner and Bean, 1987), while others found that persistence varies significantly by age: where traditional-age students were strongly influenced by encouragement, support, and academic integration, and adult students were most influenced by social integration (Crawford Sorey and Harris Duggan, 2008). Classrooms that are composed of both traditional and nontraditional students may introduce unique challenges to the students as well as the instructors, particularly as we work to adapt our classrooms to be more student-centered, using group-style, active-learning strategies. There are a number of frameworks to predict and describe how an adult learner may differ from younger learners. For example, andragogy theory, informed by constructivist and metacognitive lenses, implies that adult learners are more self-aware of their learning and therefore interact with the classroom differently than traditional-age college learners (Kegan, 1994; Mezirow, 2000; Kenner and Weinerman, 2011). Further, researchers have reported mixed views on adult learners' perceptions of their preferred strategies, including a predilection for both instructor-centered and student-centered learning, depending upon the study (see Ross-Gordon, 2003), but data are limited on how these students' performances and/ or perceptions may be similar or different from those of their peers in introductory STEM courses.

Our institution has a largely nontraditional student population that consists of students of a broad range of ages and prior college experiences, including many postbaccalaureate students (postbacs) and URM students. To begin to better understand our students' experiences, we took a coarse-grained view of the introductory majors-level biology and chemistry courses and studied how the students at a nontraditional urban university perceived and performed in their courses. Our research specifically asked,

1. What aspects of their courses do students report as influencing their learning of the subject matter, and their interest in the subject matter?

2. How do students perceive specific active-learning strategies used within a course? 
3. Are there trends in student perceptions that are aligned with student demographic traits and/or university status (e.g., postbac, traditional, or non-traditional-age undergraduate), and is there a relationship between student course performance and student perceptions or traits?

\section{METHODS}

\section{Courses Surveyed}

This study was conducted at Portland State University (PSU), a large, urban, commuter university located in downtown Portland, OR. Two sections each of 200-level introductory (for science majors) biology and chemistry courses were surveyed during a single term of the 2016-2017 academic year. Table 1 describes courses involved in the study (see Supplemental Material S5-S8 for syllabi). While the two biology sections were the same course, their structures differed. Section 1 used multiple active-learning strategies; thus section 1 is deemed Integrated-AL Biology. Section 2 was taught by a different instructor and used limited active learning and is deemed Limited-AL Biology. The chemistry sections (1 and 2) had two different instructors and were intentionally aligned regarding material and the use of multiple active-learning strategies, and thus are considered to be similar chemistry learning environments for this study and are collectively considered Integrated-AL Chemistry. All courses in this study used a classroom response system (i.e., clickers), although course instructors used the response systems in varying ways. Limited-AL Biology is deemed "limited," because the only active-learning strategy used was the classroom response system. Here, clickers were used for periodic check-ins, such as recall of recently presented information, with an average of four clicker questions per 110-minute class period. Integrated-AL Biology and Integrated-AL Chemistry also used the response systems for periodic check-ins (with an average of four to five clicker questions per 65-minute class period), but also incorporated clickers into various formative assessments, such as a mechanism to guide group-work activities and/or to facilitate think-pair-share activities. Additionally, Integrated-AL Chemistry employed process-oriented guided inquiry learning (POGIL) group-work activities weekly and outof-class online homework. Group-work activities were embedded into Integrated-AL Biology three times per term and included articles, group deliberation, and out-of-class quizzes on articles and essay questions; these activities were "Deliberative Democracy" (DD) modules originally developed for nonmajors biology and are currently being piloted and assessed in many STEM courses at our institution (Weasel and Finkel, 2016; Komperda et al., 2018). DD is a novel active-learning strategy that is intended to connect course material to realworld policy-related issues.

\section{Survey Item Development}

To gain insight into student perceptions regarding what influences their learning and interest in science, and to understand their perceptions of the instructional strategies implemented in their classrooms, we developed a series of open-ended prompts. The original wording of the prompts was, 1) "What aspects of your class experience were the most helpful to your learning and interest in science?" and 2) "How did you feel about active-learning strategies that your professor used in this class (i.e., clickers, group-work: POGIL, DD)? Please be specific about which active-learning strategy you're giving feedback on." These items were piloted in all courses as part of a larger assessment effort during the 2015-2016 academic year. Reading through and coding responses to these items, our research team recognized the ambiguity in our prompts (specifically that influences on learning and interest are separate constructs). We therefore disaggregated the questions to address learning and interest in two separate prompts and developed explicit prompts about the specific active-learning strategies in a given course. We performed think-aloud interviews on the revised questions with several students from the target populations. These modifications and interviews resulted in three new items: 1 ) "What aspect(s) of this class influenced your learning of the subject?," 2) "What aspect(s) of this class (if any) influenced your interest in the subject?," and 3) "How do you feel about the following learning strategies used in this class?" Item 3 on each survey was tailored to include only course-specific prompts for each strategy used in a given class (noted in Table 1) including: classroom response systems (clickers); POGIL (chemistry group work); and DD (biology group work).

To collect data for this study, we added the revised openended items to the end of a postcourse survey administered in STEM courses at PSU during the last week of the term. Members of the research team visited each class to announce the survey using a script and informed the students that the link to the survey was available on each course's online learning management site. The survey was administered via Qualtrics software, and all instructors offered nominal extra credit for students who accessed it. Student demographic information was collected at the end of each survey and included gender,

TABLE 1. Course descriptions

\begin{tabular}{|c|c|c|c|c|c|c|}
\hline \multirow[b]{3}{*}{ Course } & \multirow[b]{3}{*}{ Students } & \multirow[b]{3}{*}{ Room type } & \multicolumn{3}{|c|}{ In-class strategies used } & \multirow{3}{*}{$\begin{array}{c}\% \text { Final score from } \\
\text { nonsummative factors }\end{array}$} \\
\hline & & & \multirow{2}{*}{$\begin{array}{l}\text { Classroom response } \\
\text { system (clickers) }\end{array}$} & \multicolumn{2}{|c|}{ Group-work type } & \\
\hline & & & & POGIL & DD & \\
\hline $\begin{array}{l}\text { Integrated-AL Biology } \\
\text { M-W-F mornings }\end{array}$ & $\begin{array}{l}N=307 \\
\text { Study } n=179\end{array}$ & $\begin{array}{l}\text { Stadium seating, swivel } \\
\text { chairs, walkable rows }\end{array}$ & $\checkmark$ & & $\checkmark$ & 30 \\
\hline $\begin{array}{l}\text { Limited-AL Biology } \\
\text { M-W evenings }\end{array}$ & $\begin{array}{l}N=187 \\
\text { Study } n=79\end{array}$ & Fixed-row seating & $\checkmark$ & & & 10 \\
\hline $\begin{array}{l}\text { Integrated-AL Chemistry } \\
\text { M-W-F mornings }\end{array}$ & $\begin{array}{l}N=370 \\
\text { Study } n=199\end{array}$ & $\begin{array}{l}\text { Stadium seating, swivel } \\
\text { chairs, walkable rows }\end{array}$ & $\checkmark$ & $\checkmark$ & & 24 \\
\hline $\begin{array}{l}\text { Integrated-AL Chemistry } \\
\text { Tu-Th afternoons }\end{array}$ & $\begin{array}{l}N=310 \\
\text { Study } n=201\end{array}$ & $\begin{array}{l}\text { Stadium seating, swivel } \\
\text { chairs, walkable rows }\end{array}$ & $\checkmark$ & $\checkmark$ & & 24 \\
\hline
\end{tabular}

aNonsummative factors include clicker points, online quizzes, homework, group work, writing assignments, etc. 
race/ethnicity, university major, age, university status (postbaccalaureate or undergraduate), and whether students transferred to PSU from a 2-year college. Complete course grade records were obtained from the instructors and/or the online grade platform (Desire2Learn) after the term, and incoming student GPA was accessed via an institutional database. Owing to differences in course point allocations and classroom activities, scores for each student are broken into two categories: 1 ) final course score is their percent score earned in the course (0-100+\%, as assigned by the instructor); and 2) their nonsummative grade factor, which was calculated as: final course score - percent of earned summative (e.g., exams and final exams) points possible. For example, if a student earned $87 \%$ for their summative (exam) points, and their final course score was $90 \%$, the nonsummative grade factor was $3 \%$, representing the percentage points gained through nonsummative work. This grade factor allows for the consistent evaluation of the influence of nonsummative scores on final course score. Only students who consented to have their data be used in education research are represented in this study. The study was approved by the PSU IRB (\#153524).

\section{Focus Groups}

We conducted focus groups during the 2016-2017 academic year to identify whether the open-ended prompts were accurately capturing the spectrum of student perceptions. Students were recruited from introductory STEM courses via email and were offered a $\$ 10$ gift card for their participation in a focus group. A total of 30 students from five introductory STEM courses participated in seven focus groups. Each focus group session was conducted by two researchers (including L.R.-G.) and was videoand audio-recorded for transcription purposes. Volunteer participants were informed that the recordings would be destroyed after transcription and data collection. Focus group transcripts were open-coded and then compared with the themes arising from the open-ended survey questions (L.R.-G., E.E.S., J.B.).

\section{Data Analysis}

Using content analysis to uncover emergent themes from the open-ended items, we developed an initial coding rubric based on the 2015-2016 survey responses. Two researchers documented recurring themes from the responses (including L.R.-G.), and three members of the research team discussed the themes and consolidated them into overarching codes (E.E.S., L.R.-G.). Additional themes were added to the rubric as they arose from the newly worded items administered to students in the 2016-2017 academic year. Once a comprehensive coding rubric was iteratively developed (see Supplemental Tables S1 and S2), two researchers coded small batches of student responses until $>80 \%$ interrater reliability was consistently established. Following this, $20 \%$ of all responses were coded with $>85 \%$ interrater reliability among two researchers (L.R.-G., C.S.). One researcher coded the remainder of the student responses and conferred with the other researcher, coming to consensus if there were ambiguities regarding specific student responses (L.R.-G.). Individual student responses often fell into more than one code category, and were coded as such.

Student responses to the third prompt, asking how they felt about each specific strategy used in each class, were coded as positive, negative, both, or neutral. The same iterative coding methods were used (L.R.-G., C.S.). As more than one strategy was used in the Integrated-AL Chemistry and Biology courses, each student in these courses was assigned a course-specific positivity score based on the number of possible strategies to which they were exposed. For example, in the Integrated-AL Biology course, students were asked about two strategies: clickers, and DD (biology group work) -if their answers were coded as positive for both strategies, they would have a positivity score of 2 , if they were coded as making a positive statement about one of the two strategies, their score would be a 1 , and if they made negative statements about each strategy, they received a score of 0 .

Focus group transcripts were analyzed by two researchers who came to consensus about all themes that arose related to students' interest in and learning of course material. These themes were then compared against the coding rubric developed from the open-ended questions (L.R.-G., E.E.S., J.B.).

Statistical analyses were performed on statistical software (SAS JMP Pro 2012, SAS Institute, Cary, NC): Pearson's chisquare tests were used when testing for relationships among categorical variables (contingency tables), $t$ tests or one-way analysis of variance (ANOVA) were used to compare mean final course score (\%) and GPA among different groups; mixedmodel analyses were used when examining the interaction of URM and non-URM by student status (traditional/nontraditional age). Tukey's honestly significant difference (HSD) post hoc analyses were used to make among-group comparisons. We used linear regression to investigate correlation between undergraduate GPA and course scores. All reported significance was determined by $p$ values $\leq 0.05$.

\section{RESULTS}

\section{Study Population}

In total, 601 individual students are represented in the final data set. During this term, students could have been enrolled in both the biology and chemistry courses surveyed, as the courses are often taken in parallel. Because the surveys were intended to capture course-level responses, each usable survey response per course was counted as an individual data point, resulting in 658 accessed surveys. For each counted response, a student must have 1) consented to have his or her responses to be used for research and 2) completed at least one of the three openended prompts at the end of the survey. Overall, 57 of the total responses (9\%) were from students represented at two timesonce from a biology course and once from a chemistry course.

We report sample demographics of the 601 individuals in Table 2 as follows: gender; race/ethnicity as either non-URM (white/Caucasian and Asian/Pacific Islander) or URM (African American/Black, Latino/a, Middle Eastern, Native American, and multiracial); participants self-identified as undergraduate or postbaccalaureate (postbac) and indicated whether or not they had transferred to PSU from a 2-year college. We binned students as being of "traditional" age (18-22 years old) or "nontraditional" age (23+ years old) per Choy (2002). Student declared majors were organized into four categories: Biology, Chemistry, other STEM, and non-STEM. Other STEM majors included general science, engineering, computer science, environmental studies, geology, health studies, mathematics, and physics. NonSTEM majors included art, business, psychology, sociology, political science, geography, economics, and English. More than 70\% of surveyed postbac students who declared their future goals 
TABLE 2. Study sample demographics $(n=601)$

\begin{tabular}{lrlr}
\hline Category & Percent & Category & Percent \\
\hline Gender & \multicolumn{3}{c}{ Major } \\
Female & 56 & Biology & 35 \\
Male & 44 & Chemistry & 7 \\
Other/did not respond & 1 & Other STEM & 49 \\
Race/ethnicity & & Non-STEM & 9 \\
Non-URM & 74 & University status & \\
URM & 26 & Postbaccalaureate & 13 \\
Did not respond & 2 & Undergraduate & 86 \\
Age bracket (years) & & Transfer status & \\
18-22 (traditional) & 60 & Transfer from 2-year college & 25 \\
23+ (nontraditional) & 40 & & \\
\hline
\end{tabular}

reported them as being in health and/or science. Aggregate demographic traits of the study sample are representative of PSU's general undergraduate population. We focused statistical analyses on what may be predicted as salient and broad categories of student groups at PSU, including age group, student status (postbac or undergraduate), transfer (from 2-year college) or nontransfer, and race/ethnicity (URM or non-URM).

\section{Gauging Student Perceptions of What Influenced Their Learning}

The first open-ended prompt addressed student perceptions of what they perceived influenced their learning of the science in their courses. The themes, descriptors, and examples of student quotes that comprised a theme are reported in Table 3, and the coding rubric can be found in Supplemental Table S1. The themes reported by $>5 \%$ of the study population were: In-Class Strategies (45\%), Outside (course-related) Resources (38\%), Professor (30\%), Group Work (17\%), Personal Interest/Application (9\%), Classroom Community (8\%), and Labs/Workshops (7\%). Some students made statements that fell into more than one theme; therefore, the percentages of themes add up to more than $100 \%$. Disaggregated response themes by course type (Limited-AL Biology, Integrated-AL Biology, and Integrated-AL Chemistry) are presented in Table 4. There were significant differences among the proportion of responses by course type for two of the seven themes, as indicated by the asterisks in Table 4.

Overall, postbacs were significantly more likely than undergraduates of any age to identify Professor as being influential ( $n=567$; Pearson chi-square $=14.79 ; p=0.002)$. There were no other significant trends by student group across all courses. Yet we also looked at student perceptions of what influenced their learning in the Integrated-AL classrooms (Biology and

TABLE 3. Top student responses regarding "What aspect(s) of this class influenced your learning of the subject?"

\begin{tabular}{lc}
\hline Theme ( $n=567$ responses) & Descriptors \\
\hline $\begin{array}{l}\text { In-Class Strategies } \\
45 \%\end{array}$ & $\begin{array}{c}\text { Any strategy used during class } \\
\text { time, including lecture, videos, } \\
\text { classroom response systems } \\
\text { (clickers), slides, etc. }\end{array}$ \\
$\begin{array}{l}\text { Outside (course-related) } \\
\text { Resources }\end{array}$ & $\begin{array}{c}\text { Materials that are provided by the } \\
\text { course/professor that can be }\end{array}$ \\
$38 \%$ & used outside class time
\end{tabular}

Professor

$30 \%$

Group Work

$17 \%$

\begin{abstract}
Personal Interest/Application Student holds interest in a topic, $9 \%$

Classroom Community $8 \%$ student makes a real-life connection with the material Student mentions peers, friends, and/or study groups
\end{abstract}

Student refers to the professor's teaching style, interest in the material

Includes mention of POGIL, DD, other group-work activities, including worksheets/ discussions

Laboratories/Workshops $7 \%$

Student refers to the workshop or lab section of the course

\section{Sample quotes}

"The lecture itself along with clicker questions supported my learning. It was a nice break from course materials." (Biology)

"The clicker questions, good way to see an example question and get an answer and explanation to how it's done." (Chemistry)

"Having the lectures being recorded was very useful in case I didn't totally grasp a concept in class, I could easily go back and watch it over again. I also liked the PowerPoints being available on D2L to look over on my own and do some more studying accompanying the textbook." (Biology)

"Mastering chemistry [online homework] was good practice, I used it to study for tests and it worked great. The book was also good." (Chemistry)

"The instructor's enthusiasm!!! Her passion and interest in the subject was of the highest importance." (Biology)

"[The professor] does a good job of going through the steps and explaining each step or concept well. I like [the] worksheets and the fact that [the professor] posts answers later on D2L." (Chemistry)

"I think the [DD] are supplemental and are great for applying what I already know in biology to solving some of the issues the world has today. It's also great to discuss topics with peers and obtain additional perspectives." (Biology)

"I believe that the group work [POGIL] aspect of the class helped me connect with my fellow classmates and learn how to do things from others." (Chemistry)

"Understanding more about diseases and medicines." (Biology)

"The chemistry of acids and bases and the cell-batteries." (Chemistry)

"I also made friends with some fellow classmates, and being able to study together or ask each other questions was very useful in helping me learn and understand the material." (Biology)

"Being able to make friends greatly contributed to my learning. Attending a class with over 250 students can be lonely if you do not know anyone." (Chemistry)

"Hands on in labs helps." (Biology)

"I really enjoyed the attached Chemistry workshop because the TA provided a lot of help with working through the tougher problems that we don't necessarily have a lot of time to practice during lecture." (Chemistry) 
TABLE 4. Top student responses regarding: "What aspect(s) of this class influenced your learning of the subject?" by course type ${ }^{a}$

\begin{tabular}{lccc}
\hline & $\begin{array}{c}\text { Limited-AL } \\
\text { Biology \% } \\
(\boldsymbol{n}=\mathbf{6 3})\end{array}$ & $\begin{array}{c}\text { Integrated-AL Integrated-AL } \\
\text { Biology \% } \\
(\boldsymbol{n}=\mathbf{1 5 2})\end{array}$ & $\begin{array}{c}\text { Chemistry \% } \\
(\boldsymbol{n}=\mathbf{3 5 2})\end{array}$ \\
Theme & 41 & 53 & 43 \\
In-Class Strategies & 35 & 38 & 40 \\
$\begin{array}{l}\text { Outside (course-related) } \\
\quad \text { Resources }\end{array}$ & 22 & 30 & 32 \\
Professor & $\mathrm{n} / \mathrm{a}$ & 9 & 24 \\
Group Work*** & 19 & 11 & 6 \\
Personal Interest/ & & & \\
$\quad$ Application** & 10 & 3 & 8 \\
Laboratories/Workshops & 6 & 5 & 9 \\
Classroom Community & & & \\
\hline
\end{tabular}

aSignificant differences among responses by course as determined by Pearson's chi-square test: ${ }^{* *}, p \leq 0.001 ;{ }^{* * *}, p \leq 0.0001$. Many students had responses that fell into more than one theme.

Chemistry) only, as themes such as Group Work were not represented in the Limited AL Biology classroom (as to be expected). Upon analysis of the Integrated-AL classrooms, postbacs higher likelihood to identify Professor as influential remained ( $n=504$; Pearson chi-square $=17.22$; $p=0.002$ ), but there were other intriguing trends that emerged. In-Class Strategies was reported significantly less often by transfer students than nontransfer students $(n=504$; Pearson chi-square $=4.45$; $p=0.04$ ). Although nonsignificant, we saw a trend in traditional-age undergraduates being more likely to discuss both Group
Work $(p=0.11)$ and Community ( $p=0.06)$ factors as influencing their learning in the classroom over either non-traditionalage undergraduates or postbacs. There were no detected differences between URM and non-URM students' perceptions of learning influences in either all courses combined or the Integrated-AL courses only.

\section{Gauging Student Perceptions of What Influenced Their Interest}

The second open-ended prompt addressed student perceptions of what they felt influenced their interest in the science in their courses. The themes, descriptors, and examples of student quotes are reported in aggregate in Table 5, and the coding rubric can be found in Supplemental Table S2. The top themes reported by $>5 \%$ of the study population were: Specific Subject/Topic (32\%), Subject/Topic Application to Real Life (22\%), Professor (16\%), In-Class Strategies (8\%), Laboratories/Workshops (8\%), Group Work (6\%), and Relates to Career Goals $(6 \%)$. Students may have discussed more than one theme in their response; thus, theme categories do not sum to $100 \%$. There were significant differences detected among the proportion of responses by course type for five of the themes, as indicated by asterisks in disaggregated data presented in Table 6 . Undergraduate students (of all ages) were significantly more likely to state that Specific Subject/Topic influenced their interest in the course material over postbacs $(n=466$; Pearson chisquare $=6.03 ; p=0.05)$. No other differences were detected among any evaluated student groups regarding self-reported

TABLE 5. Top student responses for "What aspect(s) of this class (if any) influenced your interest in the subject?

\begin{tabular}{|c|c|c|}
\hline Theme ( $n=466$ responses) & Descriptors & Sample quotes \\
\hline $\begin{array}{l}\text { Specific Subject/Topic } \\
32 \%\end{array}$ & $\begin{array}{l}\text { Student mentions a particular } \\
\text { topic(s) he or she has interest in }\end{array}$ & $\begin{array}{l}\text { "An aspect of this class that influenced my interest in science, is that I } \\
\text { always had an interest in wanting to learn more about DNA, how life } \\
\text { came to be, and cells." (Biology) } \\
\text { "Talking about the atomic spectrum, Lewis structure, and solubility } \\
\text { influenced my interests in science." (Chemistry) }\end{array}$ \\
\hline $\begin{array}{l}\text { Subject/Topic Application to } \\
\quad \text { Real Life } \\
22 \%\end{array}$ & $\begin{array}{l}\text { Student mentions real-life } \\
\text { applications for the material }\end{array}$ & $\begin{array}{l}\text { "Real life applications like gene therapy or saturated fats in foods" } \\
\text { (Biology) } \\
\text { "Real world applications. Chemistry relates directly to the real world and } \\
\text { can be used to explain many interesting phenomena that occur } \\
\text { within it." (Chemistry) }\end{array}$ \\
\hline $\begin{array}{l}\text { Professor } \\
16 \%\end{array}$ & $\begin{array}{l}\text { Student refers to the professor's } \\
\text { teaching style, interest in the } \\
\text { material }\end{array}$ & $\begin{array}{l}\text { "Professor's enthusiasm." (Biology) } \\
\text { "The teacher makes the class very fun and interesting. [The professor is] } \\
\text { very helpful and supportive and I would love to take another class of } \\
\text { chemistry because of [the professor]." (Chemistry) }\end{array}$ \\
\hline $\begin{array}{l}\text { In-Class Strategies } \\
8 \%\end{array}$ & $\begin{array}{l}\text { Any strategy used during the class } \\
\text { time, including lecture, videos, } \\
\text { classroom response system, etc. }\end{array}$ & $\begin{array}{l}\text { "The lectures where we used videos on the topic were helpful and } \\
\text { interesting." (Biology) } \\
\text { "[The professor] made the lectures somewhat entertaining and not } \\
\text { as intimidating as the stuff I would read out of the textbook." } \\
\text { (Chemistry) }\end{array}$ \\
\hline $\begin{array}{l}\text { Laboratories/Workshops } \\
8 \%\end{array}$ & $\begin{array}{l}\text { Student refers to the workshop or } \\
\text { lab section of the course }\end{array}$ & $\begin{array}{l}\text { "The lab was fun and made me more interested in biology." (Biology) } \\
\text { "One thing that influenced my interest would be the lab. I enjoy to do } \\
\text { hand-on things so that I can learn and understand why something } \\
\text { will occur." (Chemistry) }\end{array}$ \\
\hline $\begin{array}{l}\text { Topic Relates to Career Goals } \\
6 \%\end{array}$ & $\begin{array}{l}\text { Student mentions subjects/topics } \\
\text { that relate to school/career } \\
\text { goals }\end{array}$ & $\begin{array}{l}\text { "Learning about molecular structures. Will help a lot with medical } \\
\text { school."(Chemistry) } \\
\text { "Genetics applies to my career in healthcare." (Biology) }\end{array}$ \\
\hline $\begin{array}{l}\text { Group Work } \\
6 \%\end{array}$ & $\begin{array}{l}\text { POGIL, DD, other group-work activ- } \\
\text { ities, including worksheets/ } \\
\text { discussions }\end{array}$ & $\begin{array}{l}\text { "I thought that [the DD] were good at piquing my interest in specific } \\
\text { fields of biology." (Biology) } \\
\text { "Having stable groupmates to work with helped me stay focused, } \\
\text { interested, and accountable this term." (Chemistry) }\end{array}$ \\
\hline
\end{tabular}


TABLE 6. Top student responses (\%) for "What aspect(s) of this class (if any) influenced your interest in the subject?" by course type ${ }^{a}$

\begin{tabular}{lccc}
\hline & $\begin{array}{c}\text { Limited-AL } \\
\text { Biology \% } \\
(\boldsymbol{n}=\mathbf{6 3 )}\end{array}$ & $\begin{array}{c}\text { Integrated-AL Integrated-AL } \\
\text { Biology \% } \\
(\boldsymbol{n}=\mathbf{1 3 5})\end{array}$ & $\begin{array}{c}\text { Chemistry \% } \\
(\boldsymbol{n}=\mathbf{2 6 8})\end{array}$ \\
Theme & 33 & 34 & 27 \\
\hline Specific Subject/Topic & 25 & 25 & 20 \\
$\begin{array}{l}\text { Subject/Topic } \\
\quad \text { Application to }\end{array}$ & & & \\
$\quad$ Real Life & 11 & 11 & 20 \\
Professor* & 0 & 6 & 11 \\
$\begin{array}{l}\text { In-Class Strategies*** } \\
\text { Group Work*** }\end{array}$ & $\mathrm{n} / \mathrm{a}$ & 16 & 2 \\
Laboratories/ & 10 & 4 & 9 \\
$\quad$ Workshops* & & & 7 \\
Relates to Career Goals & 5 & 5 &
\end{tabular}

aSignificant differences among responses by course as determined by Pearson's chisquare test: *, $p \leq 0.05 ; * *, p \leq 0.001 ;{ }^{* * *}, p \leq 0.0001$. Many students had responses that fell into more than one theme.

influences on interest in the course material, neither in all courses combined nor in the Integrated-AL courses only.

\section{Student Focus Groups}

A total of 30 students participated in focus groups regarding the learning and interest prompts. Independent open-coding of focus group responses revealed themes similar to those that arose from the open-ended prompts administered on the survey. Specific themes can be found in Supplemental Tables S3 and S4. While not every theme identified in the survey responses arose within the focus groups, it is encouraging that no new themes arose in the group discussions. As open-ended responses can be seen as taxing to students being surveyed, these data support the survey responses accurately reflecting student perceptions.

\section{Student Perceptions of Active Learning}

The third open-ended prompt addressed student perceptions of how they felt about the strategies used in their courses (Figure 1). Students in all courses had overwhelmingly positive remarks about the use of clickers (84\%) with only $21 \%$ offering negative comments. In Integrated-AL Chemistry, group work was more evenly split, with $60 \%$ of students speaking positively and $47 \%$ negatively. In Integrated-AL Biology, student comments were $80 \%$ positive and $42 \%$ negative regarding group work. Some students made both a positive and a negative comment about

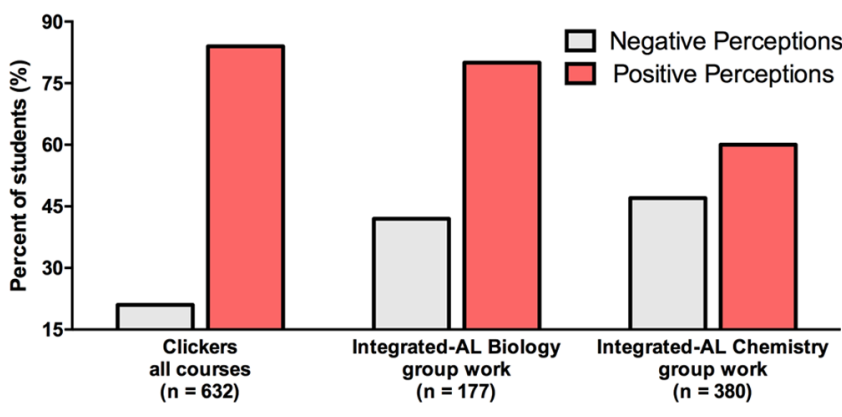

FIGURE 1. Students have positive attitudes about the active-learning strategies used in their courses. Students responded to each open-ended question regarding specific strategies used in their courses. Responses that were coded as positive or negative are represented. In total, $21 \%$ of student responses were negative and $84 \%$ were positive about clickers. Students had negative comments about group work in Integrated-AL Biology $42 \%$ of the time, and $80 \%$ had positive perceptions, while group-work in Integrated-AL Chemistry was perceived negatively by $47 \%$ of the students, and $60 \%$ had positive things to say. Totals do not add up to $100 \%$, as many students had multiple perspectives in each open-ended response, each of which was coded.

strategy; both were counted. A relatively small number of student responses could not be coded as positive or negative, but were coded as neutral (e.g., "It [strategy] was fine"). We do not present neutral data; only positive and/or negative examples of student quotes are provided in Table 7. Disaggregated responses by course type show the relative percent of positive and negative perceptions of each strategy by course (Table 8). Limited-AL Biology students were significantly more likely to say something negative about clickers $(n=632$; Pearson chi-square $=33.0 ; p<0.0001$ ) and less likely to have something positive to say about clickers $(n=631$; Pearson chi-square $=40.1 ; p<$ 0.0001 ). One significant difference found between groups of students was that URM students were significantly less likely to have a positive perception of DD (biology group work; $n=177$; Pearson chi-square $=4.71 ; p=0.04$ ), and non-traditional-age students and postbacs were significantly more likely to have negative perceptions of clickers than traditional-age students ( $n$ $=632$; Pearson chi-square $=8.28 ; p=0.02$ ). Here we note that postbacs are mostly of nontraditional age (64\%), yet $36 \%$ of non-traditional-age students are not postbacs; therefore, these specific reported data have the potential to be somewhat

TABLE 7. Student perceptions of learning strategies

\begin{tabular}{|c|c|c|}
\hline Learning strategy & Positive & Negative \\
\hline $\begin{array}{r}\text { Classroom response } \\
\text { system (clickers) }\end{array}$ & $\begin{array}{l}\text { "I like the [clickers]. They give the teacher a good } \\
\text { place to see where the class is at and explain } \\
\text { concepts more thoroughly if need be. It's also a } \\
\text { better way to gauge attendance than calling out } \\
\text { everyone's name." (Biology) }\end{array}$ & $\begin{array}{l}\text { "I just wish the iClickers were cheaper since the course requires } \\
\text { so many different materials, which makes it even more } \\
\text { expensive than it already is. This can be very discouraging } \\
\text { for students who wish to take the class but are very short on } \\
\text { funds (which most of us are)." (Chemistry) }\end{array}$ \\
\hline POGIL & $\begin{array}{l}\text { "I think that this strategy [POGIL] is helpful because I } \\
\text { am able to get help and learn from other people } \\
\text { along with making friends." (Chemistry) }\end{array}$ & $\begin{array}{l}\text { "There wasn't enough motivation for everyone to participate." } \\
\text { (Chemistry) }\end{array}$ \\
\hline DD & $\begin{array}{l}\text { "They [DD] are really interesting because they make } \\
\text { the topics that we learn in class more relatable to } \\
\text { the real world." (Biology) }\end{array}$ & $\begin{array}{l}\text { "[DD] Waste of time... Can't believe we lost class periods that } \\
\text { could have been spent covering skipped lecture topics." } \\
\text { (Biology) }\end{array}$ \\
\hline
\end{tabular}


TABLE 8. Course-specific student attitudes about group work ${ }^{\mathrm{a}}$

\begin{tabular}{|c|c|c|c|c|c|c|}
\hline \multirow[b]{2}{*}{ Course } & \multicolumn{3}{|c|}{ Classroom response system (clickers) } & \multicolumn{3}{|c|}{ Group work } \\
\hline & $n$ & $\%$ positive & $\%$ negative & $n$ & $\%$ positive & $\%$ negative \\
\hline Limited-AL Biology ${ }^{\mathrm{b}}$ & 74 & 58 & 46 & $\mathrm{n} / \mathrm{a}$ & $\mathrm{n} / \mathrm{a}$ & $\mathrm{n} / \mathrm{a}$ \\
\hline Integrated-AL Chemistry & 385 & 87 & 17 & 380 & 60 & 47 \\
\hline
\end{tabular}

aSome students reported both positive and negative feeling about strategies; therefore, response categories total $>100 \%$.

bStudents in Limited-AL Biology were significantly more likely to say something negative about clickers and were significantly less likely to say something positive compared with the other two courses $(n=632)$.

confounded by age. However, with postbac students excluded from the data, the trend remains the same-non-traditional-age students are more likely to perceive clickers negatively. We found no additional correlations or trends in attitudes toward specific active-learning strategies among groups.

For each student, a "positivity score" was determined based on their response to each strategy-specific open-ended prompt. In Integrated-AL Biology and in Integrated-AL Chemistry, a positivity score could range from 0 to 2 , reflecting the number of specific strategies used, and Limited-AL Biology students' scores could range from 0 to 1 . In Limited-AL Biology $(n=79), 46 \%$ did not say anything positive about clickers (therefore a 0 ), and $54 \%$ had a positive perception (a 1). Of students in Integrated-AL Biology ( $n=178$ ), $5 \%$ had a score of 0 (student had zero positive things to say about active-learning strategies), $28 \%$ had a score of 1 (student had positive things to say about either of the strategies), and $68 \%$ had a score of 2 (student had positive things to say about both strategies). For Integrated-AL Chemistry $(n=$ 400 ), $21 \%$ had a score of $0,38 \%$ had a score of 1 , and $52 \%$ had a score of 2 . These scores are used as a proxy for attitude toward classroom strategies in subsequent analyses.

\section{Student Course Performance}

In all three course types, current student GPA was a significant predictor of final course score (Limited-AL Biology, $R^{2}=0.28$; Integrated-AL Biology, $R^{2}=0.61$; and Integrated-AL Chemistry, $R^{2}=0.46$; all $p<0.0001$ ). There were significant differences in current GPA among a few student groups. URM student mean current GPAs $(n=152 ; x=3.01$, SEM $=0.04$ ) were lower than
non-URM $(n=435 ; x=3.18$, SEM $=0.03 ; F=10.0 ; p=0.002)$. We also detected differences between postbac mean current GPAs $(n=80 ; x=3.37$, SEM $=0.06 ; F=16.5 ; p<0.0001)$, and undergraduates $(n=519 ; x=3.09$, SEM $=0.02)$. Nontraditional-age student mean current GPAs $(n=237 ; x=3.08$, $\mathrm{SEM}=0.04)$ were lower than traditional-age student GPAs $(n=$ $362 ; x=3.16, \mathrm{SEM}=0.03 ; F=2.73 ; p=0.10$ ), although not significantly so. Transfer status did not impact GPA.

The highest mean final course score was in Integrated-AL Biology $(x=86.7 \%$, SEM $=0.01)$, followed by Integrated-AL Chemistry mean final course score $(x=77.9 \%$, SEM $=0.00)$, and Limited-AL Biology ( $x=70.5 \%$, SEM $=0.12$ ). We also calculated and compared separate scores for summative points and for nonsummative points (nonsummative grade factor). Summative scores in all courses significantly predicted final course scores.

\section{Student Attitude Toward AL Does Not Impact Final Course Score or Summative Grade Factor}

No significant differences were detected among average final course score or summative grade factors and student attitude, as determined by their positivity scores in any of the courses (Figure 2).

\section{Student Final Course Scores Differ by Student Status}

Postbac students had the highest mean final course scores across the entire sample $(x=85.8 \%, \mathrm{SEM}=1.25 ; n=94)$ compared with all undergraduates $(x=78.5 \%$, SEM $=0.53 ; t=$ 4.79; $n=563 ; p<0.0001)$. Traditional-age undergraduates
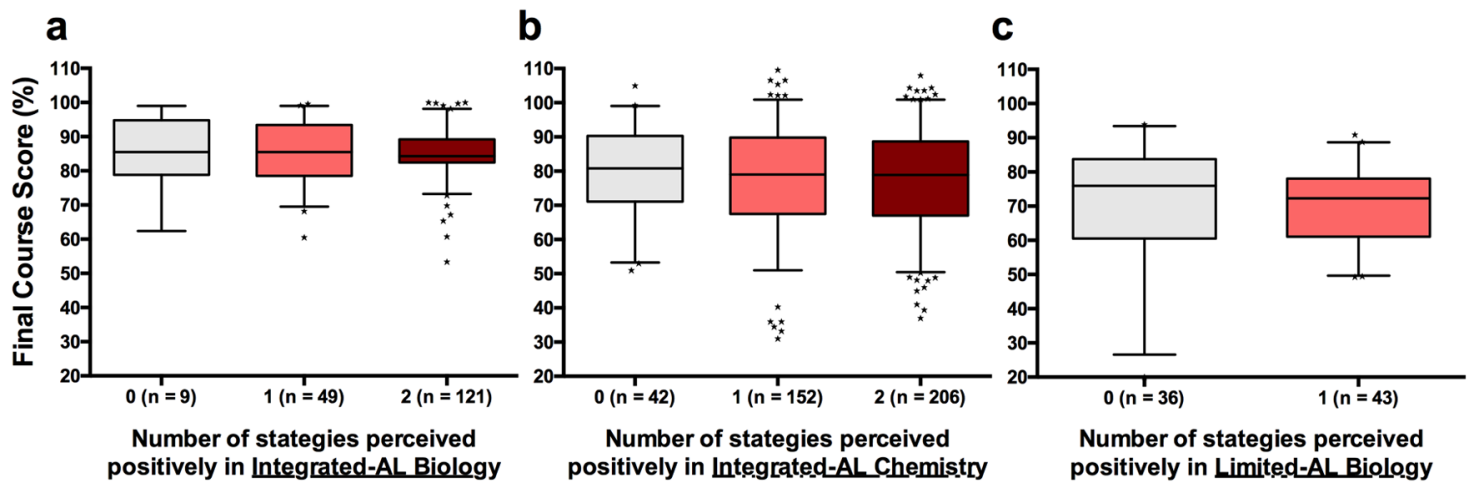

FIGURE 2. Student attitudes about active-learning strategies are not correlated to final course grades. (a) Integrated-AL Biology courses and (b) Integrated-AL Chemistry courses both used two distinct active-learning strategies, while (c) Limited-AL Biology used one distinct strategy. Box plots compare final course scores of students with varying positivity. Boxes define the data quartiles, and whiskers represent the 5th and 95th percentiles. Midline represents the median course score, and stars are data points falling outside of the 5th to 95th percentile. 
a

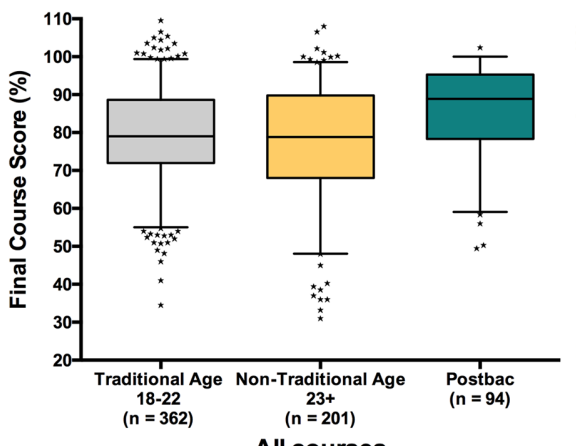

All courses

C
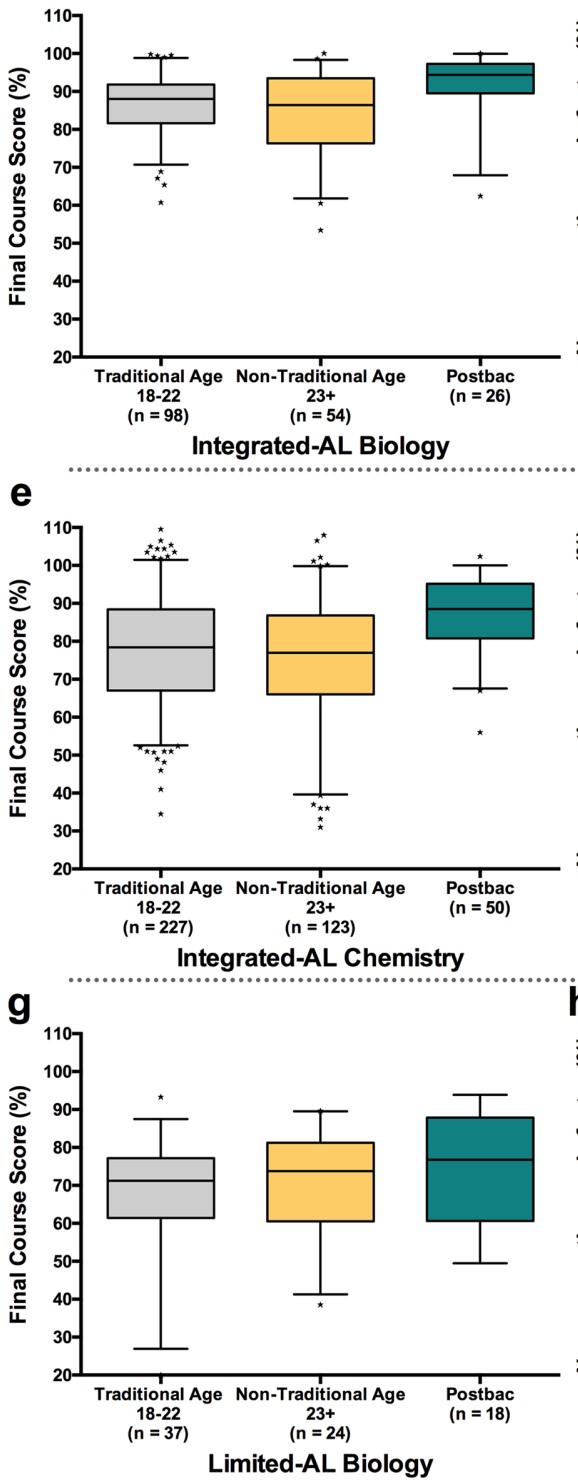

b

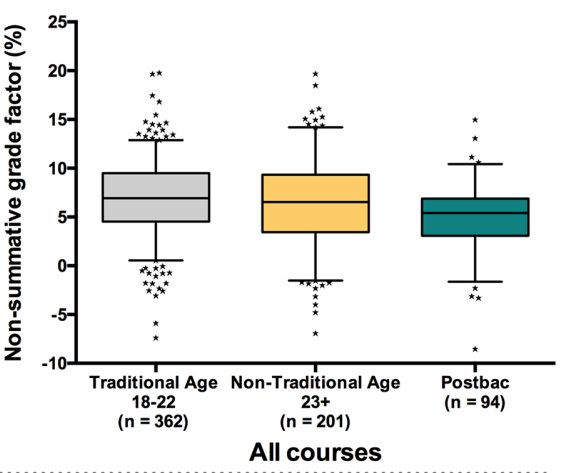

d
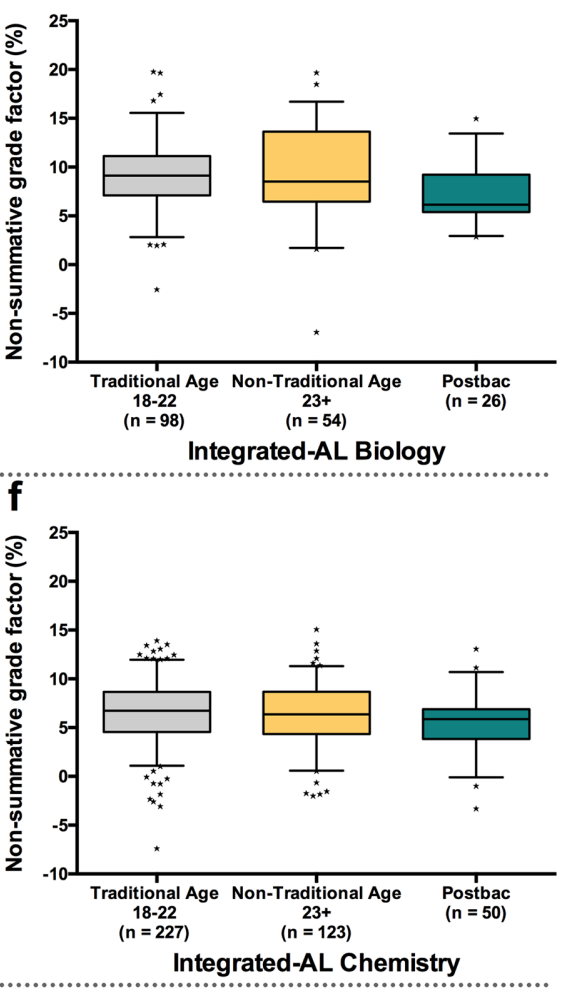

h

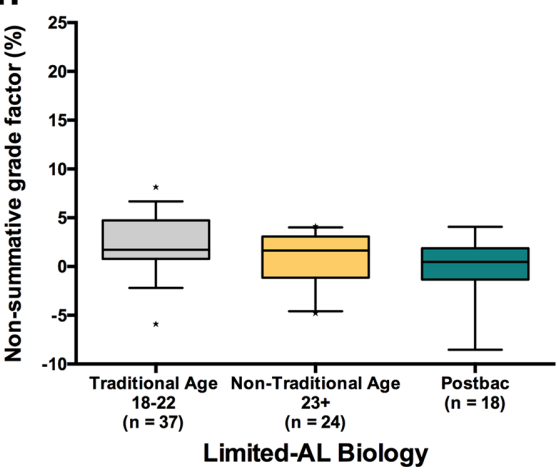

FIGURE 3. Postbacs have high final course scores and low nonsummative grade factors across courses. Box plots compare final course scores of students by age and university status. (a) Across courses, postbac students have the highest mean final course score, ( $n=$ $657 ; F=11.76 ; p<0.0001$ ), and traditional-age undergraduates have higher final course grades than non-traditional-age students. (b) Postbac students across courses have a significantly lower nonsummative grade factors than undergraduates of all ages $(n=657$;

(18-22 years) have higher mean final course scores $(n=362 ; x=79.3 \%$, SEM $=$ $0.68 ; t=1.8 ; p=0.07$; Figure $3 \mathrm{a})$ than non-traditional-age undergraduates $(23+$ years, nonpostbacs) ( $n=201 ; x=77 \%$, SEM $=01.11$ ). Although the differences between traditional- and non-traditional-age students were not significant within each course, the trend of traditional students outperforming students aged 23+ persists in the Integrated-AL courses, but not in the Limited-AL course. In each course, postbacs outperform undergraduates of all ages, significantly so in Integrated-AL Biology $(n=178 ; F=6.07, p=$ 0.003; Figure $3 c$ ) and in Integrated-AL Chemistry $(n=400 ; F=10.68 ; p<0.0001$; Figure $3 \mathrm{e}$ ), and similarly but nonsignificant in Limited AL Biology $(n=79 ; F=$ $1.17 ; p=0.31$; Figure $3 g$ ). There were no significant differences in final course scores among subgroups of postbacs (e.g., by age or URM status).

We further analyzed the data without postbacs to better understand the rest of the population. Here, we found that URM students have, on average, significantly lower final course scores $(n=157 ; x=$ $75.0 \%$, SEM $=0.01$ ) than non-URM students $(n=395 ; x=79.9 \%$, SEM $=0.01 ; F$ $=12.04, p=0.0006)$. There were no significant differences among age groups, although traditional-age students had slightly higher mean final course scores than non-traditional-age students, as did non-transfer students over transfer students. Because active learning is intended

$F=8.36 ; p=0.0003$ ). (c) Postbacs outperform undergraduates in Integrated-AL Biology final course scores $(n=178 ; F=6.07$, $p=0.003$ ). (d) Integrated-AL Biology postbacs have significantly lower nonsummative grade factors than undergraduates ( $n=178 ; F=3.28 ; p=0.04)$. (e) Postbacs outperform undergraduates in Integrated-AL Chemistry final course scores $(n=400 ; F=$ 10.68; $p<0.0001$ ). (f) Integrated-AL

Chemistry postbacs have nonsignificantly lower nonsummative grade factors $(n=400$; $F=1.9 ; p=0.15)$. (g) Postbacs outperform undergraduates in Limited AL Biology $(n=$ 79; $F=1.17 ; p=0.31$ ), but not significantly so. (h) Limited-AL Biology postbacs also had significantly lower nonsummative grade factors $(n=79 ; F=4.23 ; p=0.02)$. Boxes define the data quartiles, and whiskers represent the 5th and 95th percentiles. Midline represents the median course score, and stars are data points falling outside of the 5th to 95 th percentile. 
a

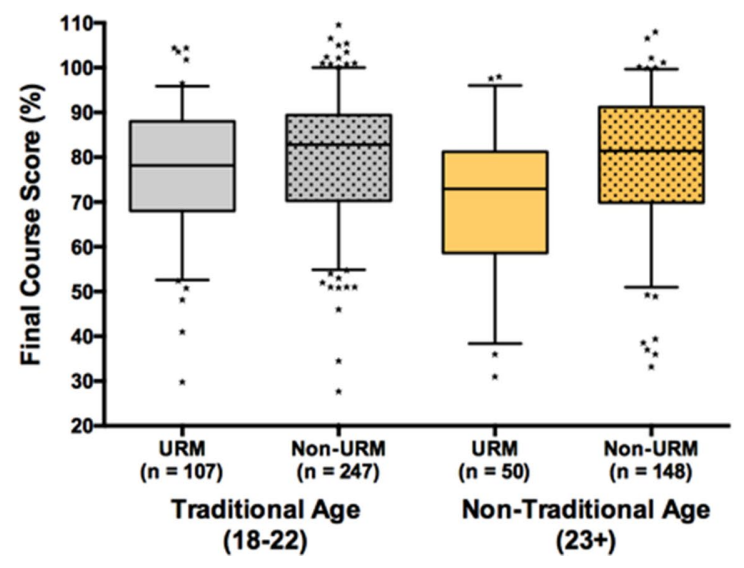

b

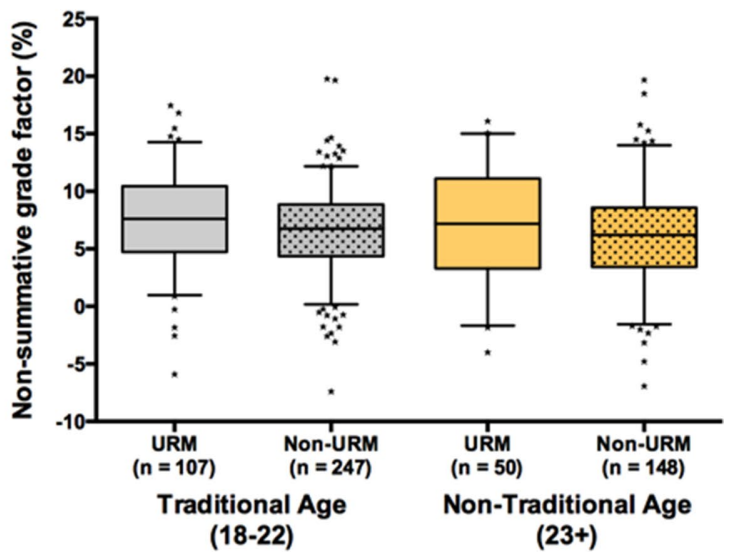

FIGURE 4. URM students have low final course scores but benefit from nonsummative grade factors. Box plots compare final course scores of students by age and URM status. (a) Final course grades differ significantly among the four student groups (URM traditional age, URM nontraditional age, non-URM traditional age, non-URM nontraditional age) significantly $(n=552 ; F=6.07 ; p<0.0005)$. (b) Final nonsummative course scores differ significantly among the same student groups $(n=552 ; F=2.62 ; p=0.05)$. Boxes define the data quartiles, and whiskers represent the 5 th and 95 th percentiles. Midline represents the median course score, and stars are data points falling outside of the 5 th to 95 th percentile.

to close the achievement gap between URM students and nonURM students, we also looked at performance of URM students in the two age groups (two potential factors in underperformance) and found significant differences in final course score means ( $n=552 ; F=6.07 ; p=0.0005$ ). Tukey's HSD post hoc analyses reveal that non-traditional-age URM students underperform compared with other students, while traditional-age non-URM students are the top-performing students in all courses (Figure 4a), once postbacs are excluded. We see the same trend in each course; however, due to low sample sizes and the focus of the study, we did not further analyze those disaggregated data. We did not include undergraduates who chose not to report race/ethnicity $(n=11)$.

\section{Nonsummative Grade Factor}

The number of total course points possible that were nonsummative differed by class (Table 1), with Limited-AL Biology having $10 \%$ of the final points coming from nonsummative course factors, Integrated-AL Biology 30\%, and Integrated-AL Chemistry $24 \%$. The mean numbers of nonsummative grade factors earned by students in each course are therefore different. On average, Limited-AL Biology students' nonsummative grade factor was $1 \%$, Integrated-AL Biology was $9 \%$, and Integrated-AL Chemistry was $6 \%$. This means that, on average, students earned a 1-9\% boost in their final course scores over their summative (i.e., exams and final) scores alone. Postbac students across all classes have significantly lower nonsummative grade factors than undergraduates of all ages $(n=657 ; F=8.36$; $p=$ 0.0003; Figure 3b). This trend remains for all three courses. Integrated-AL Biology postbacs have significantly lower nonsummative grade factors $(n=178 ; F=3.28$; $p=0.04$; Figure $3 d)$; the same is true for Limited AL Biology ( $n=79 ; F=4.23$; $p=0.02$; Figure $3 \mathrm{~h}$ ) and Integrated-AL Chemistry, but was not significant $(n=400 ; F=1.9 ; p=0.15$; Figure $3 f$ ).

We also evaluated the undergraduate-only (postbacs excluded) nonsummative grade factors by disaggregated stu- dent groups (age group and URM status) and found that URM students were earning significantly higher nonsummative grade factors (on average $7 \%$ vs. $6 \% ; n=552 ; t=1.96 ; p=0.02$ ); and when we examined URM status and age status, there was a small significant difference among means ( $n=552 ; F=2.62$; $p=0.05$ ). Traditional-age URM students earned the highest nonsummative grade factors, and non-URM, non-traditionalage students the lowest (Figure 4b). There were no significant differences for transfer students, although non-transfer students earned slightly higher than average nonsummative grade factors.

\section{DISCUSSION}

What Impacts Student Learning?

We found there was a fairly homogeneous set of factors that students self-identify as influencing their learning of biology and chemistry, and these factors deviate little by student group. Rising to the top of students' open-ended responses were In-Class Strategies (45\%), which admittedly are variable, and could range from lecture to clicker questions to videos; yet in each course, this theme was the most prevalent (Table 4). However, 2-year college transfer students were significantly less likely than non-transfer students to cite these influences in our Integrated-AL classes. We hypothesize that the transfer students may see our classrooms differently than non-transfer students due to stark environmental differences between community college campuses and a large, urban commuter university. Non-transfer students may have already had one or more large-capacity lecture courses, in which they were one of hundreds of students sitting in a room, potentially with very little to no student-centered activities; therefore, in-class strategies may be perceived differently. Thus, doing group work and using clickers in the large lecture classroom may have presented an opportunity for non-transfer students to feel that they could meaningfully engage with other students and the professor, building a "sense of belonging" (Hoffman et al., 2002), whereas 
the experience may feel impersonal compared with a more intimate community college environment. Feelings of not belonging at a large university are documented impacts of the transfer process, leading to elements of "transfer shock" (Hagerty et al., 1996; Pennington, 2006; Hausmann et al., 2007), although, contrary to what might be predicted, our transfer students are doing as well in our classes (performance-wise) as non-transfer students. We plan to more deeply investigate possible differences among our transfer and non-transfer students in hopes of better understanding the challenges these students may face.

Perhaps unsurprisingly, it was the top-achieving students in the courses, the postbacs (students who already have an undergraduate degree), who most frequently identified Professor as being influential to their learning. Although we do not count attendance as a factor in our data, these data provide an argument for encouraging students to come to class, as it is highly likely that a student who cites professors (often by name) or specific details on what occurs during class (in-class strategies) as being most impactful for their learning is benefiting from being present in class. Outside Resources were cited by a number of students (38\%), and most prevalently by students regarding their Integrated-AL Chemistry courses (Table 4). This higher prevalence in Integrated-AL Chemistry is likely due to the required use of Mastering Chemistry for completing online homework assignments. This type of outside resource was not required in the biology courses.

Interestingly, the Limited-AL Biology course students were more likely than Integrated-AL Biology students to cite Laboratories/Workshops being important to their learning, even though the laboratories for both biology courses were identical and were composed of students from both sections in the same laboratory classes. It is possible that without active-learning activities embedded in the lecture classroom, laboratories present more of a welcome, hands-on experience, whereas the Integrated-AL Biology students are engaged in the learning process more frequently, and thus may not think of the labs as readily. A moderate percentage of Integrated-AL Biology and Integrated-AL Chemistry student responses were related to Group Work being influential to their learning of the subject, which is encouraging, because certain activities are embedded into the curriculum (such as DD and POGIL) that are meant to enhance student learning as well as interest in science. Most of the students in these classes are biology majors, thus it is not surprising that the Personal Interest/Application theme was more regularly cited in both biology courses than in chemistry, as students likely connect more with intrinsic interest if they are pursuing biology and/or pre-health than chemistry.

We were surprised that we did not detect differences in perceptions of the classroom between traditional- and nontraditional-age students. One study found that younger students perceive the classroom differently (Strage, 2008), more like high school, while other studies, similar to ours, did not find significant differences in traditional- and non-traditionalage students' predictors of their academic goals (Spitzer, 2000). If there are differences, it seems that a finer-grained study will be needed to detect those variations in perceptions among our student groups; however, it may be useful for instructors of various classrooms, particularly those with student populations similar to ours, to know how students perceive factors that most influence their learning.

\section{What Impacts Student Interest?}

Interest in STEM is thought to be a key predictor of persistence in a STEM major (PCAST, 2012); thus, understanding how students conceptualize their own interests deserves attention. In this study, students report the influence that both similar and different aspects of their courses have on their interest in science compared with their learning of science. Many of the students (32\%) indicated that Specific Subjects/Topics from the course content interested them, and many other students (22\%) took it further, indicating that they felt specific topics from the course were pertinent to their own lives or could be applied to their lives (Table 5). We thought that focus groups might elucidate more themes regarding what influences students' interest; however, the focus groups essentially revealed the same broad categories described by the open-ended survey items, just with more personal examples (Table 5 and Supplemental Tables SI, S3, and S4). We did find some course-specific factors that influence interest (Table 6). Notably, Integrated-AL Biology students offered that aspects of Group Work influenced their interest, which is likely due to the nature of the group work itself in Integrated-AL Biology, which was often tied to "real-life" policy and current issues that directly impact human lives. If we aim to appeal to our students' interests, understanding what they perceive as impactful is a key first step.

\section{Student Attitudes Vary Regarding Specific AL Strategies}

Students offered quite a bit of positive feedback around the use of clickers in the classrooms (84\%; Figure 1 and Table 7), yet this positivity was significantly more prevalent in the Integrated-AL classrooms, where clickers were used with higher frequency in more varied evidence-based ways (e.g., to guide group-work activities; Table 8). Other than lecture, classroom response systems are arguably the strategy that students have the most exposure to (Mayer et al., 2009) and may be used in a variety of courses given the relative ease with which a professor can embed clickers into lecture. The other strategies predictably led to more mixed attitudes, although the majority of students had positive things to say about all strategies (Figure 1 and Table 8). Given the more even split in positivity, particularly regarding the POGIL group work in chemistry, the next steps will be to further disaggregate the positive and negative responses and dive deeper into course-level differences and similarities in the group-work experience (e.g., worksheet format, relative point allocation) that may influence a student's attitude. Work is underway as part of a larger evaluation plan of the pedagogy to better understand the specific factors that influence a student's experience with DD.

\section{Student Attitude about Classroom Strategies Does Not Impact Performance, Yet Performance Is Highly Divergent} We expected to see that student attitude toward the courses' strategies (indicated by the positivity score), particularly in the Integrated-AL courses, would correlate with student grades (i.e., more positive attitude, better grades, and vice versa), but we detected no evidence for this relationship (Figure 2). The lack of correlation, however, does support the stance that, even if there is student pushback regarding the use of student-centered strategies in the classroom, our students are not being negatively impacted (at least in performance) by the use of strategies they do not necessarily perceive positively. 
Most interesting, and also most disconcerting, is that, although students generally perceive the classroom environment similarly regarding influences on their interest and learning and their attitudes toward the classroom, there are still significant performance differences among student groups (Figures 3 and 4). We do not yet have the information needed to help us better understand why this is occurring. Gaining a broad view regarding the students in our classes was the first step in working to build a more equitable classroom. The fact that incoming GPA is strongly positively correlated with final course score in all courses, however, confounds the data, as our non-traditional-age (23+ years) and URM students enter majors-level introductory science courses with lower GPAs than their peers. Here, we are not necessarily creating the gap, but upon a coarse-grained view, we are also not mitigating it-at least as it relates to final course scores.

When we took a more nuanced view of classroom performance, we found that nonsummative grade factors have the smallest impact on the highest group of performers (postbacs) and the greatest impact on URM students' final course scores compared with their peers. Although URM student final course scores are significantly lower, looking at performance in this disaggregated way allowed us to identify that perhaps we are making incremental steps toward closing the achievement gap. At the same time, non-traditional-age students showed the least impact from nonsummative grade factors; again, different student groups may be responsive to different classroom strategies or environments. There are a number of factors that may impact a student's performance on a summative assessment, and now that we have identified gaps, exploring ways to mitigate these factors, such as exam preparation activities and explicit programs (Gilmer, 2007; Harackiewicz et al., 2014), would be a good start. And clearly, building nonsummative course factors into class structures can be impactful. Now that we have identified that these performance differences exist, the next steps will be conducting studies at a finer grain to begin to understand the unique classroom experiences of these students.

\section{Postbacs Are a Distinctly Different Student Population in the Classroom}

There are clearly two, if not three or four, distinct populations of students in these introductory courses at our urban, commuter university. In many ways, having such diverse students in the classroom is a positive aspect of any university experience (Birnbaum, 1983; Gurin et al., 2002). Here, students interact with others whose lives are not like theirs-which is arguably a reason to go to college and expand one's worldview beyond one's personal experiences. However, at least in our case, the postbacs (in aggregate) are outperforming other students, even though, for the most part, their perceptions of the classroom environment are indistinguishable from those of their peers. Postbacs earned significantly fewer nonsummative grade points than other students, yet continued to outperform across the board in final course scores. Postbac students will seemingly succeed regardless of classroom strategies used, which in isolation is certainly not negative; however, it could compound other student groups' struggles-particularly in courses that "curve" grades. There are well-founded arguments for not curving course grades (e.g., Schinske and Tanner, 2014), and the data presented here offer yet another.
Postbac student success makes sense, because these students have already completed a degree, whereas other students have not, and they likely are more metacognitive about their learning and have figured out how to be successful in the college classroom-as would be predicted by theory on adult learning (Ross-Gordon, 2003; although not all of our postbacs were "older," non-traditional-age students; some were 22 or younger). There is also the fact that postbacs are not typically eligible for most funding opportunities; therefore, they may be highly driven to succeed, as they could be paying out of pocket and/or adding to their student loan debt. Postbacs are mostly pre-health at our university and therefore may have more welldeveloped goals and motivations as they prepare to apply for entrance into programs (medical, dental, physical therapy, etc.).

We acknowledge that our reflections on returning students' outperformance may not be surprising, but we aim to stress how important it is to discuss this disparity, particularly at institutions like ours. Identifying specific factors that motivate and influence postbac success will be important as we continue work to unravel the similarities and differences among our student groups. To our knowledge, there are minimal studies highlighting this very salient issue in today's STEM classrooms. There is much to be understood about how postbac experiences may differ from their near-peer experiences, perhaps particularly in introductory or "gateway" courses. To uncover these differences, we believe that more in-depth qualitative work must be conducted such that we can compare and contrast the factors that lead to differential student success by age or university status. Many instructors may not be aware of the fraction of students in their classes who have earned a degree already or even know the ages of their current students. It seems that having such institutional knowledge would enable an instructor to make efforts to modify teaching strategies if he or she found inequitable outcomes among student groups. Although classroom strategies were perceived mostly similarly among student groups at our institution, the outcomes do not reflect equity, and we presume that other institutions may also reveal disparities between perceptions or attitudes and course performance or anticipated outcomes. These data support the need for more inquiry into how various student groups, namely postbacs, may impact the classroom learning environment and course outcomes.

\section{Limitations}

These data are self-reported and thus are subject to inflation and/or understatement of students' actual experiences (Bowman, 2011), yet our focus group data support the open-ended survey response data, and we felt that allowing students to respond to open-ended prompts, as opposed to a list of possible responses, would be more indicative of the most salient influences and perspectives. We believe that the themes that arose are robust enough to inform the development of a tool designed to gauge factors that influence student learning and interest in their science courses. These data represent students at only one institution and may not be representative of biology and chemistry students elsewhere. In every classroom there are nuances that may influence student perception and performance. Unfortunately, we did not have the opportunity to use a classroom observation tool (e.g., the COPUS tool; Smith et al., 2013) that 
would have provided us with a finer-grained view of the various classroom environments, yet all of the classrooms reported on were informally observed by the researchers. Finally, while we agree with arguments that final course score is not the best outcome measure, in most institutions, this is the measure that leads to a letter grade, which informs a student's still-important GPA. We believe that understanding how a student engages with and performs on nonsummative activities, and the level to which those activities are weighted by the instructor, are important factors to consider as we continue to make efforts to understand how our classroom efforts impact all of our students.

\section{CONCLUSIONS}

We found that there are predictable associations that students have regarding what influences their learning and interest in science and that they are generally positive about active-learning strategies. However, their attitudes about classroom strategies do not relate to their course performance. Importantly, these data highlight the view that simply adopting and embedding active learning into the classroom will not necessarily impact all students to the same extent. In particular, at institutions with large nontraditional student populations, it is imperative to begin to disaggregate how students perceive and perform in their courses, and then address the factors that may influence differences.

\section{ACKNOWLEDGMENTS}

We thank the students and instructors who either participated or gave extra credit for participation and Kathryn Hosbein and Emily Olsen for help with data collection. We also thank the three anonymous $L S E$ reviewers for their helpful suggestions for revision. This research was supported in part by an award to PSU under the Howard Hughes Medical Institute Science Education Program (award 52008105 to G.P.S.).

\section{REFERENCES}

Ames, C. (1992). Classrooms: Goals, structures, and student motivation Journal of Educational Psychology, 84(3), 261.

Birnbaum, R. (1983). Maintaining diversity in higher education. San Francisco: Jossey-Bass. ERIC no. ED243339

Bonwell, C. C., \& Eison, J. A. (1991). Active learning: Creating excitement in the classroom (1991 ASHE-ERIC higher education reports). Washington, DC: ERIC Clearinghouse on Higher Education. ERIC no. ED336049.

Bowman, N. A. (2011). Validity of college self-reported gains at diverse institutions. Educational Researcher, 40(1), 22-24.

Brazeal, K. R., Brown, T. L., \& Couch, B. A. (2016). Characterizing student perceptions of and buy-in toward common formative assessment techniques. CBE-Life Sciences Education, 15(4), ar73.

Cavanagh, A. J., Aragón, O. R., Chen, X., Couch, B. A., Durham, M. F., Bobrownicki, A., ... Graham, M. J. (2016). Student buy-in to active learning in a college science course. CBE-Life Sciences Education, 15(4), ar76. doi: 10.1187/cbe.16-07-0212

Choy, S. (2002). Nontraditional undergraduates: Findings from "The Condition of Education, 2002." Washington, DC: National Center for Education Statistics. ERIC no. ED471077.

Crawford Sorey, K., \& Harris Duggan, M. (2008). Differential predictors of persistence between community college adult and traditional-aged students. Community College Journal of Research and Practice, 32(2), 75100. doi: $10.1080 / 10668920701380967$

Dolan, E. L. (2015). Biology education research 2.0: CBE-Life Sciences Education, 14(4): ed1.

Doyle, W. R. (2010). Open-access colleges responsible for greatest gains in graduation rates. San Jose, CA: National Center for Public Policy and Higher
Education. Retrieved November 1, 2017, from http://highereducation.org/ pa_0210/index.shtml

Eddy, S. L., Brownell, S. E., \& Wenderoth, M. P. (2014). Gender gaps in achievement and participation in multiple introductory biology classrooms. CBE-Life Sciences Education, 13(3), 478-492.

Eddy, S. L., \& Hogan, K. A. (2014). Getting under the hood: How and for whom does increasing course structure work? CBE-Life Sciences Education, 13(3), 453-468.

Freeman, S., Eddy, S. L., McDonough, M., Smith, M. K., Okoroafor, N., Jordt, H., \& Wenderoth, M. P. (2014). Active learning increases student performance in science, engineering, and mathematics. Proceedings of the National Academy of Sciences USA, 111(23), 8410-8415.

Gilmer, T. C. (2007). An understanding of the improved grades, retention and graduation rates of STEM majors at the Academic Investment in Math and Science (AIMS) Program of Bowling Green State University (BGSU). Journal of STEM Education: Innovations Research, 8(1), 11-21.

Gurin, P., Dey, E., Hurtado, S., \& Gurin, G. (2002). Diversity and higher education: Theory and impact on educational outcomes. Harvard Educational Review, 72(3), 330-367.

Haak, D. C., HilleRisLambers, J., Pitre, E., \& Freeman, S. (2011). Increased structure and active learning reduce the achievement gap in introductory biology. Science, 332(6034), 1213-1216.

Hagerty, B. M., Williams, R. A., Coyne, J. C., \& Early, M. R. (1996). Sense of belonging and indicators of social and psychological functioning. Archives of Psychiatric Nursing, 10(4), 235-244.

Handelsman, J., Ebert-May, D., Beichner, R., \& Bruns, P. (2004). Scientific teaching. Science, 304(5670), 521.

Harackiewicz, J. M., Canning, E. A., Tibbetts, Y., Giffen, C. J., Blair, S. S., Rouse, D. I., \& Hyde, J. S. J. (2014). Closing the social class achievement gap for first-generation students in undergraduate biology. Journal of Educational Psychology, 106(2), 375.

Hausmann, L. R., Schofield, J. W., \& Woods, R. L. (2007). Sense of belonging as a predictor of intentions to persist among African American and white first-year college students. Research in Higher Education, 48(7), 803-839.

Herreid, C. F., \& Schiller, N. A. (2013). Case studies and the flipped classroom. Journal of College Science Teaching, 42(5), 62-66.

Hoffman, M., Richmond, J., Morrow, J., \& Salomone, K. (2002). Investigating "sense of belonging" in first-year college students. Journal of College Student Retention: Research, Theory \& Practice, 4(3), 227-256.

Jensen, J. L., \& Lawson, A. (2011). Effects of collaborative group composition and inquiry instruction on reasoning gains and achievement in undergraduate biology. CBE-Life Sciences Education, 10(1), 64-73.

Johnson, D. W., Johnson, R. T., \& Smith, K. A. (1998). Cooperative learning returns to college what evidence is there that it works? Change: The Magazine of Higher Learning, 30(4), 26-35.

Kegan, R. (1994). In over our heads: The mental demands of modern life. Cambridge, MA: Harvard University Press.

Kenner, C., \& Weinerman, J. J. (2011). Adult learning theory: Applications to non-traditional college students. Journal of College Reading and Learning, 41(2), 87-96.

Komperda, R., Barbera, J., Shortlidge, E. E., \& Shusterman, G. P. (2018) Connecting chemistry to community with deliberative democracy. In Citizens first! Democracy, social responsibility and chemistry (Vol. 1297, pp. 81-98). Washington, DC: American Chemical Society.

Lizzio, A., Wilson, K., \& Simons, R. (2002). University students' perceptions of the learning environment and academic outcomes: Implications for theory and practice. Studies in Higher Education, 27(1), 27-52.

Machemer, P. L., \& Crawford, P. (2007). Student perceptions of active learning in a large cross-disciplinary classroom. Active Learning in Higher Education, 8(1), 9-30.

Mayer, R. E., Stull, A., DeLeeuw, K., Almeroth, K., Bimber, B., Chun, D., .. Zhang, H. (2009). Clickers in college classrooms: Fostering learning with questioning methods in large lecture classes. Contemporary Educational Psychology, 34(1), 51-57.

Metzner, B. S., \& Bean, J. P (1987). The estimation of a conceptual model of nontraditional undergraduate student attrition. Journal of Research in Higher Education, 27(1), 15-38.

Meyers, C., \& Jones, T. B. (1993). Promoting active learning. Strategies for the college classroom. San Francisco: Jossey-Bass. ERIC no. ED358757. 
Mezirow, J. (2000). Learning as transformation: Critical perspectives on a theory in progress. San Francisco: Jossey-Bass. ERIC no. ED448301.

Michael, J. (2006). Where's the evidence that active learning works? Advances in Physiology Education, 30(4), 159-167.

National Center for Education Statistics. (2017). Fast facts: Back to school statistics. Retrieved December 1, 2017, from https://nces.ed.gov/ fastfacts/display.asp?id=372

National Research Council. (2003). BIO2010: Transforming undergraduate education for future research biologists. Washington, D.C.: National Academies Press. https://doi.org/10.17226/10497

Pennington, R. (2006). Rethinking grade transfer shock: Examining its importance in the community college transfer process. Journal of Applied Research in the Community College, 14(1), 13-27.

President's Council of Advisors on Science and Technology. (2012). Engage to excel: Producing one million additional college graduates with degrees in science, technology, engineering, and mathematics. Washington, DC: U.S. Government Office of Science and Technology.

Prince, M. (2004). Does active learning work? A review of the research. Journal of Engineering Education, 93(3), 223-231. doi: 10.1002/j.2168-9830 2004.tb00809.x

Ross-Gordon, J. M. (2003). Adult learners in the classroom. New Directions for Student Services, 2003(102), 43-52

Schinske, J., \& Tanner, K. (2014). Teaching more by grading less (or differently). CBE-Life Sciences Education, 13(2), 159-166.

Smith, M. K., Jones, F. H. M., Gilbert, S. L., \& Wieman, C. E. (2013). The Classroom Observation Protocol for Undergraduate STEM (COPUS): A new instrument to characterize university STEM classroom practices. CBELife Sciences Education, 12(4), 618-627. doi: 10.1187/cbe.13-08-0154

Spitzer, T. M. (2000). Predictors of college success: A comparison of traditional and nontraditional age students. NASPA Journal, 38(1), 82-98.

Strage, A. (2008). Traditional and non-traditional college students' descriptions of the "ideal" professor and the "ideal" course and perceived strengths and limitations. College Student Journal, 42(1), 225-232.

Tanner, K., \& Allen, D. (2004). Approaches to biology teaching and learning: Learning styles and the problem of instructional selection-engaging all students in science courses. Cell Biology Education, 3(4), 197-201.

Tanner, K., Chatman, L. S., \& Allen, D. (2003). Approaches to cell biology teaching: Cooperative learning in the science classroom-beyond students working in groups. Cell Biology Education, 2(1), 1-5.

Tanner, K. D. (2011). Reconsidering "what works." CBE-Life Sciences Education, 10(4), 329-333.

Watkins, J., \& Mazur, E. (2013). Retaining students in science, technology, engineering, and mathematics (STEM) majors. Journal of College Science Teaching, 42(5), 36-41.

Weasel, L. H., \& Finkel, L. (2016). Deliberative pedagogy in a nonmajors biology course: Active learning that promotes student engagement with science policy and research. Journal of College Science Teaching, 45(4), 38.

Welsh, A. J. (2012). Exploring undergraduates' perceptions of the use of active learning techniques in science lectures. Journal of College Science Teaching, 42(2), 80 .

Yuretich, R. F. (2003). Encouraging critical thinking. Journal of College Science Teaching, 33(3), 40. 